\title{
Activity-based management as economic effect measurement for implementing ISO 9001:2015 clause
}

\section{Muhammad Rosiawan}

Department of Industrial Engineering, Institut Teknologi Sepuluh Nopember, Surabaya 60111, Indonesia

and

Department of Industrial Engineering, Universitas Surabaya Indonesia, Indonesia

Email:mrosiawan@staff.ubaya.ac.id

\section{Moses Laksono Singgih and Erwin Widodo*}

\author{
Department of Industrial Engineering, \\ Institut Teknologi Sepuluh Nopember, \\ Surabaya 60111, Indonesia \\ Email: moseslsinggih@ie.its.ac.id \\ Email: erwin@ie.its.ac.id \\ *Corresponding author
}

\begin{abstract}
This paper aims to measure the overhead costs and economic effects of applying ISO 9001 clauses in manufacturing companies. The activity-based management (ABM) approach is used to allocate cost objects and to trace the source of costs for high-cost activities when implementing the ISO 9001 clause. Inbound logistics processes, which consist of purchasing raw materials and warehouse processes, were used as the research objects for implementing the ISO 9001 clause. From the results of the numerical calculations based on the conceptual models and mathematical equations developed, the company obtained cost savings first from a reduction in high-cost activities and second, from the performance targets achieved. However, companies need to consider the number of performance indicators in the business processes precisely. This is because it affects the cost savings obtained and the return period of investment in the ISO 9001 implementation programs.
\end{abstract}

Keywords: activity-based management; ABM; ISO 9001; overhead cost; cost savings; payback period.

Reference to this paper should be made as follows: Rosiawan, M., Singgih, M.L. and Widodo, E. (2021) 'Activity-based management as economic effect measurement for implementing ISO 9001:2015 clause', Int. J. Services and Operations Management, Vol. 40, No. 1, pp.1-22.

Biographical notes: Muhammad Rosiawan is a Doctoral student and a quality management trainer. He obtained his BSc in Statistics from the Institut Teknologi Sepuluh Nopember, Surabaya-Indonesia, and his Master's of Engineering in Industrial Engineering from the Institut Teknologi Bandung, Indonesia. His research interest includes quality and integrated management system. 
Moses Laksono Singgih is a Professor of Productivity and Quality in the Department of Industrial Engineering at the Institut Teknologi Sepuluh Nopember. He obtained his Master's at the Industrial Engineering, Institut Teknologi Bandung, Indonesia and his $\mathrm{PhD}$ in Industrial Economics from the University of Queensland, Australia. His current research interest is in productivity and quality in manufacturing systems including internet of things, design for longevity, cost of quality, modularity design for product and process, maintenance for leased equipment, new product development for inactive problems, risk management for DFMA.

Erwin Widodo is a researcher in Department of Industrial Engineering at the Institut Teknologi Sepuluh Nopember. He obtained his Master's of Engineering in Information Science and System Engineering from the Ritsumeikan University, and Doctoral Engineering in Systems Cybernetic/Graduate School of Engineering from the Hiroshima University. His research interest includes logistics, production/operations management, and supply chain.

\section{Introduction}

ISO 9001 is an international standard for quality management systems. It is a tool used by management companies used to ensure the organisation's process quality and improvement in performance (Aba et al., 2016; Khalili et al., 2018). Surveys have been conducted to identify the advantages of standardisation and certification in a company. The surveys show that the respondents have a positive attitude towards standardisation and certification because they

a increase the quality of the processes therein and reduce re-working and scrap

b result in on-time delivery

c improve company image

d increase sales (Tzelepis et al., 2006; Psomas and Pantouvakis, 2015).

Other benefits of standardisation are increasing the level of safety, the product efficiency, the financial performance and the quality of raw material from the suppliers (Starke et al., 2012; Rosiawan et al., 2018). However, organisations need to analyse and evaluate the benefits of implementing and certifying ISO 9001 to improve organisational performance and to ensure that it is greater than the costs spent (Antunes et al., 2018).

In the ISO (2013), they developed a methodology to analyse the economic benefits of keeping to a certain standard. Using this methodology, companies can measure the economic benefits gained from implementing standardisation based on a number of performance targets achieved. Unfortunately, the methodology was not able to identify and analyse the relationship between the costs of the quality improvement program and its economic benefits. As a result, organisations cannot measure and compare the costs spent with the economic benefits accurately.

As an instrument for quality improvement, cost of quality (CoQ) refers to an amount of money spent on developing and maintaining the quality of a product, service or process (Schiffauerova and Thomson, 2006). According to Malik et al. (2016), the total CoQ spent on quality activities is quite large, around $11 \%$ of the percentage of sales or 
$15 \%$ of the cost of raw materials. This high CoQ shows the importance of organisations when it comes to reducing the cost as part of a reduction program related to the CoQ (Sturm et al., 2019). Furthermore, to obtain significant benefits, the organisation should identify and establish operational performance indicators that provide greater economic benefits compared to the quality costs incurred (Plewa et al., 2016).

ISO 9001 implementation enables companies to carry out a quality management system effectively in order to achieve their performance targets. The company should establish the operational performance in each of the business processes including inbound logistics, production, outbound logistics, marketing and after-sales (ISO, 2013). Each business process should fulfil the ISO 9001 clauses. Since ISO 9001 is oriented to processes and performance, the activity-based management (ABM) approach, which is an extension of the activity-based costing (ABC) approach in the area of total quality management (TQM), is a suitable approach for measuring how effective and efficient the implementation of ISO 9001 is in a company.

By the ABM approach, companies can allocate and track the overhead costs to carry out business activities in order to comply with the ISO 9001 clause and to measure how much money they have saved by achieving the performance targets. Thus, to get the maximum cost savings, it is important for the organisation's leader to design and set the performance indicators and targets in a business process that provides significant economic benefits. When the CoQ improvement is higher than the economic benefits derived from the targets achieved, then the organisation's leader should search for new performance indicators and/or increase the level of the performance targets.

This paper aims to measure the allocation of overhead costs, to track and analyse high-cost activities as opportunities for cost reduction and to measure cost savings related to the performance targets achieved in each period. Furthermore, from calculating the accumulation of overhead costs and accumulated cost savings, the company can estimate the investment return period from the quality improvement program.

This paper is organised as follows. In Section 2, we have provided a background of the study that discusses the previous studies investigating PAF quality cost and process costs in different companies, the ABM approach to measure the overhead costs and improving the quality of business processes in various companies. Section 3 is the research methodology that explains the steps in measuring the quality costs, cost savings and payback periods. Section 4 illustration of the numerical examples of inbound logistics at the shoe companies that consist of purchasing and raw material storage warehouses. Section 5 is the findings and discussion of this study. Section 6 is the conclusion which consists of the conclusion, practical implications and recommendations for future study.

\section{Literature review}

The objective of a quality cost system is to measure the effectiveness of an investment in the quality improvement program and to ensure that the investment is cost-effective. One of the quality improvement programs is the implementation of ISO 9001. ISO 9001 is a quality management system standard used to fulfil needs and expectations, as well as to increase the customer or other stakeholder's satisfaction. Unfortunately, the cost of implementing and certifying ISO 9001 is often expensive (Antunes et al., 2018). The 
organisation's leader often asks questions about the investment of the quality improvement program, such as the questions about how much investment is needed for a quality improvement program and what impact it had on the economic benefits obtained worth the cost of the quality spent.

Depending on the type of industry, investment in a quality improvement program is estimated at around 5-25\% of the turnover (Crombie, 1993). Many quality costs are allocated for the provision of resources for the prevention and appraisal of activities needed to reduce the cost of failures (Alglawe et al., 2019; Sturm et al., 2019). As a result, companies that adopt a quality cost system have fewer internal and external failure costs compared to other companies (Kerfai et al., 2016; Farooq et al., 2017). Through increasing a higher quality level, the failure costs will significantly reduce compared to the spent costs for the prevention and appraisal activities (Sawan et al., 2018). Thus, it can be said that the implementation of quality system costs have a positive impact on the company performance, particularly on the reduction of the defect rate (Plewa et al., 2016; Regina et al., 2018). Furthermore, researchers have conducted studies on quality costs extensively and found that, in general, quality costs can be categorised as preventive-appraisal-failure (PAF) costs, process costs and ABC (Tsai, 1998; Barouch and Bey, 2018).

\subsection{PAF cost}

The PAF cost model explains that the optimum quality and minimum costs are achieved by investing in preventive/appraisal costs to reduce the failure cost. Researchers used this model to analyse PAF cost behaviour, such as:

a the reciprocal relationship between preventive-appraisal costs and failure costs

(Chopra and Garg, 2011)

b the behaviour of PAF and opportunity costs (Omar and Murgan, 2014).

In the other studies discussing PAF cost in companies applying ISO 9001, Halis and Oztas (2002) analysed quality cost for the implementation of ISO 9001 and Fons (2011) discussed the impact of ISO 9001 on the profit of the company.

Despite its popularity, several researchers argued that PAF quality costs have several limitations, and thus it might not provide valid information on quality costs. The reasons are that

a PAF cost does not involve intangible costs, such as costs for setting up quality management system documents and controls

b PAF cannot identify which classification an activity belongs to (for example, product design and development which involves both preventive and appraisal activities) (Tsai, 1998; Schiffauerova and Thomson, 2006).

\subsection{Process cost}

Process costs discuss the costs spent on quality improvement during the input, output and control system processes, as well as resource utilisation. The process cost model overcomes several drawbacks in the PAF cost, particularly classifying which category quality cost of an activity belongs to prevention or appraisal. Furthermore, the process 
cost categories (the cost of conformance and the cost of non-conformance) focused on the costs spent on conducting activities correctly for the first time and to avoid product defects (British Standard, 1992). Therefore, the process cost model might be more suitable to measure quality improvement costs. Fons (2013) developed a conceptual framework to measure the process cost in companies that apply ISO 9001.

Nevertheless, this model is too complex for the formulation of the inputs, resources, control system and outputs that are not integrated into the other business functions in a company. It cannot identify all of the activities in a process either. Goulden and Rawlins (1997) suggested that the process cost model should be followed by a flowchart of activities and processes integrated into other activities and cost forms.

\subsection{Activity-based management}

Tsai (1998) stated that there are limitations regarding collecting data about PAF and process costs, such as

a the overhead costs spent on quality improvement are unrecognisable

b the source of the quality cost being untraceable (product or department cost).

These limitations result in an inaccurate estimation of quality costs, and thus the information cannot be used to improve quality.

$\mathrm{ABC}$ is an approach that can overcome PAF and process cost limitations, particularly by measuring allocations and tracing overhead costs to its source. Overhead cost allocation can be classified into volume (such as working hours) or non-volume (such as batch, setup hour, number of department, or facility).

According to Kaplan and Anderson (2007), the ABC approach is based on information on the quality costs during the business activities, thus allowing companies to make a decision about quality improvement (zero defect and zero cost) effectively (Letza and Gadd, 1994). Zero defects or zero cost are obtained through the identification of non-cost effective activities taking place in business activities and the achievement of company targets. The expansion of the ABC approach in the TQM study area is called $\mathrm{ABM}$ and it is not only used to measure the overhead cost but also the performance target. The ABM approach is a system for monitoring and managing a business from a process perspective approach continually.

The analysis of the quality costs using the ABC approach in the business sector has not been a popular research topic. Tsai (1998) used ABC as a framework for integrated quality cost in a production department. The study discussed overhead cost allocation and tracing in order to eliminate non-added value activities within the production process. Wood (2013) used the ABC approach to calculate the cost for the suppliers of the raw material. Through this approach, the company got a return on their investment due to the decreasing defect cost and by increasing the quality of the raw materials. According to Sawan et al. (2018), if the quality of the raw material for the suppliers can be maintained effectively, then the company does not need to inspect the supplier's workplace. Thus, the cost of assessing the suppliers - which is mostly carried out through performance evaluations, audits and an analysis of the defective raw materials - can be significantly reduced (Zubar et al., 2019). Thus, the companies can also develop better supplier selection and evaluation based on quantitative and qualitative criteria (Alizadeh et al., 2016; Chatzipetrou and Moschidis, 2018). 
Success in identifying and taking corrective action (CA) for non-value added (NVA) activities means that the companies will have the ability to better understand the cycle of a product from their suppliers and within the organisation (Mazzaw and Alawamleh, 2019). In order to understand the effectiveness of the ABC approach, Hofmann and Bosshard (2017) provided three recommendations, namely:

a the importance of having a strong database

b sharing information on inter-organisation costs

c sharing the costs and benefits among the members of the supply chain.

By having a strong database, companies can trace the quality costs of the changes and then follow the cost effectiveness in real-time (Khataie and Bulgak, 2013). For example, how the $\mathrm{ABC}$ approach and strong database is used as a framework for cost savings through the three 'cost drivers' is related to the efficiency of the process design, the demand for processes and the cost of resource utilisation (Greasley and Smith, 2017).

\subsection{Quality management system and organisational performance}

According to Singh and Singh (2018), a quality management system with a continuous improvement cycle is a management approach needed in order to continually improve business process performance. Related to achieving organisational performance, Khalili et al. (2018) stated that the quality management system is not affected by sustainable organisational performance. Antunes et al. (2018) stated that the application and certification of quality management systems improves operational performance but that it does not impact financial performance. The improvement of operational performance, such as enhanced product quality, provides a competitive advantage and increases customer satisfaction, as well as improving the mutually beneficial relationships with suppliers (Modgil and Sharma, 2017; Gupta et al., 2018).

Moreover, it is difficult for the companies to measure the results of the implementation of the quality management system program. They felt that there was an internal improvement in the company but they did not know what the quantitative results were due to not knowing the methodology used to measure the economic benefits. Therefore, this study aims to assist companies in not only measuring the quality costs but also measuring the economic benefits of implementing a quality management system. In this research, all of the achievements related to operational performance were converted into units of money, such as cost savings.

\section{Research method}

The object of this study was a business process within a manufacturing company that had implemented ISO 9001. Furthermore, the inbound logistics process was selected as the research object due to the company needing to control the failure cost of the supplier's raw material and the raw material warehouse. When the suppliers send subpar raw material, the companies reject and return it to the supplier. When the company decides to accept it, the quality of the raw materials is influenced by the method of storing the raw materials in the warehouse. This may cause product defects and increase the cost of internal or external failures. 
The inbound logistic process consisted of two processes, namely the purchasing process and the raw material in the warehouse and related processes. In general, the purchasing process consists of

a the selection, evaluation and re-evaluation of supplier performance

b raw material purchasing

c the receiving and inspection of the purchased raw material

d the calibration of instruments for the raw material inspection

e sorting out the good/bad raw materials.

The process of the raw material in the warehouses consists of:

a storing/taking out the raw materials

b maintaining the warehouse infrastructure

c inspecting the quantity of the raw materials periodically

d raw materials handling.

Figure 1 Relationship among the steps of the research, the steps of the ABM approach, the ISO 9001:2015 clause within inbound logistics process and the PDCA cycle

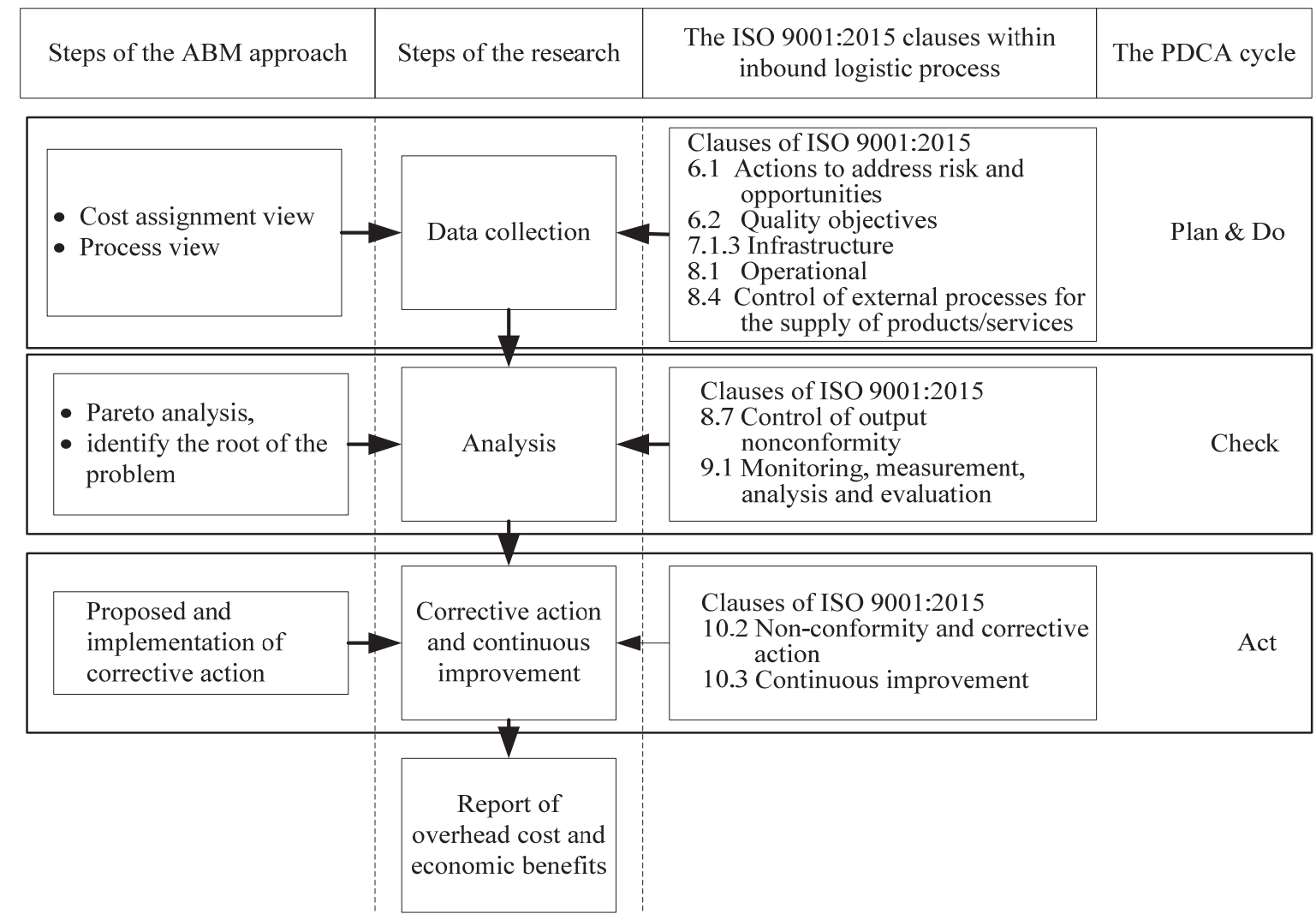

The relevant clause of ISO 9001:2015 within the inbound logistic process includes:

a planning, which includes designing actions to address the risks and opportunities related to achieving the performance targets (clause 6.1), determining the performance target (clause 6.2) and providing an infrastructure (clause 7.1.3) 
$\mathrm{b}$ the purchasing process and the storing and taking of raw materials in the warehouse (clause 8.1)

c controlling the raw materials during the receiving and inspection process (clause 8.4), as well as the storing/taking out of raw materials from the warehouse (8.1)

d conducting continuous improvement (clause 9.1, 9.3, and 10.2) (Abuhav, 2017).

The ABM approach consists of the cost assignment view and process view, the analysis of Pareto's diagram, detecting the root cause of the problem, the solution proposed and the implementation of CA. Moreover, in order to measure the overhead cost and economic impact of the implementation of ISO 9001 within the inbound logistics process, a research step was developed that linked the ISO 900:2015 clauses and the ABM approach. Deming's cycle was used to classify each step of the ABM approach, including the research steps and the ISO 9001 clause in the Plan \& Do, Check and Act (PDCA) cycle (see Figure 1).

\section{The case study for numerical examples}

The case study was conducted in a shoe factory in Sidoarjo City, Indonesia. This company has had an ISO 9001:2015 certificate since October 2016. To produce 120 pairs of shoes per day, the company needs 24 sheets of processed cow leather per day. The company purchases 700 sheets per month at a price of 300 thousand rupiah per sheet. As additional information, the working hours of the employees are 25 days per month and 8 hours per day. One employee member is responsible for the purchasing process and that of the raw material warehouse and they are paid 20 thousand rupiah per hour. In addition, the company determined that the performance target for the purchasing process is a maximum of $5 \%$ for defected raw materials from the suppliers. For the raw material in the warehouse, the maximum is $5 \%$ for defective material.

\subsection{Data collection}

According to Emblemsvag and Bras (2001), the ABM approach consists of two dimensions:

a cost assignment view

b process view (Figure 2).

Cost assignment view assumes that the object cost generates activities and that activities require resources. The allocation of the overhead cost from the resources to the cost objects involves two stages.

- Stage 1: Select a resource driver to establish the types of resources used to carry out an activity. 'Resources' refers to human, machine and facility, while 'resource drivers' refers to man hours and machine hours. In this study case, the activities within the inbound logistics can be categorised into units (e.g., 100\% inspection), batches (e.g., in-coming inspection of the supplier's raw materials) and facilities (e.g., maintenance of the raw material warehouse). 
- Stage 2: Some amount of activity cost is allocated for the object cost using the activity drivers. For example, when the object cost is the cost needed to fulfil the ISO 900:2015 clause within the inbound logistics process, then the total object cost is the total overhead cost needed to carry out all of the activities within the inbound logistic process.

The total overhead cost to carry out all of the activities within the inbound logistic process can be traced using various activity drivers such as machine hours or man hours. In this study case, the machine hours were used as a cost driver for the activity of the calibration or as the internal verification of the measurement instrument. The man-hours were used as a cost driver for the others activities. In Table 1, based on the cost assignment view, we show the use of human resource dominates rather than the machine resources.

Figure 2 Two dimensions of the ABM approach

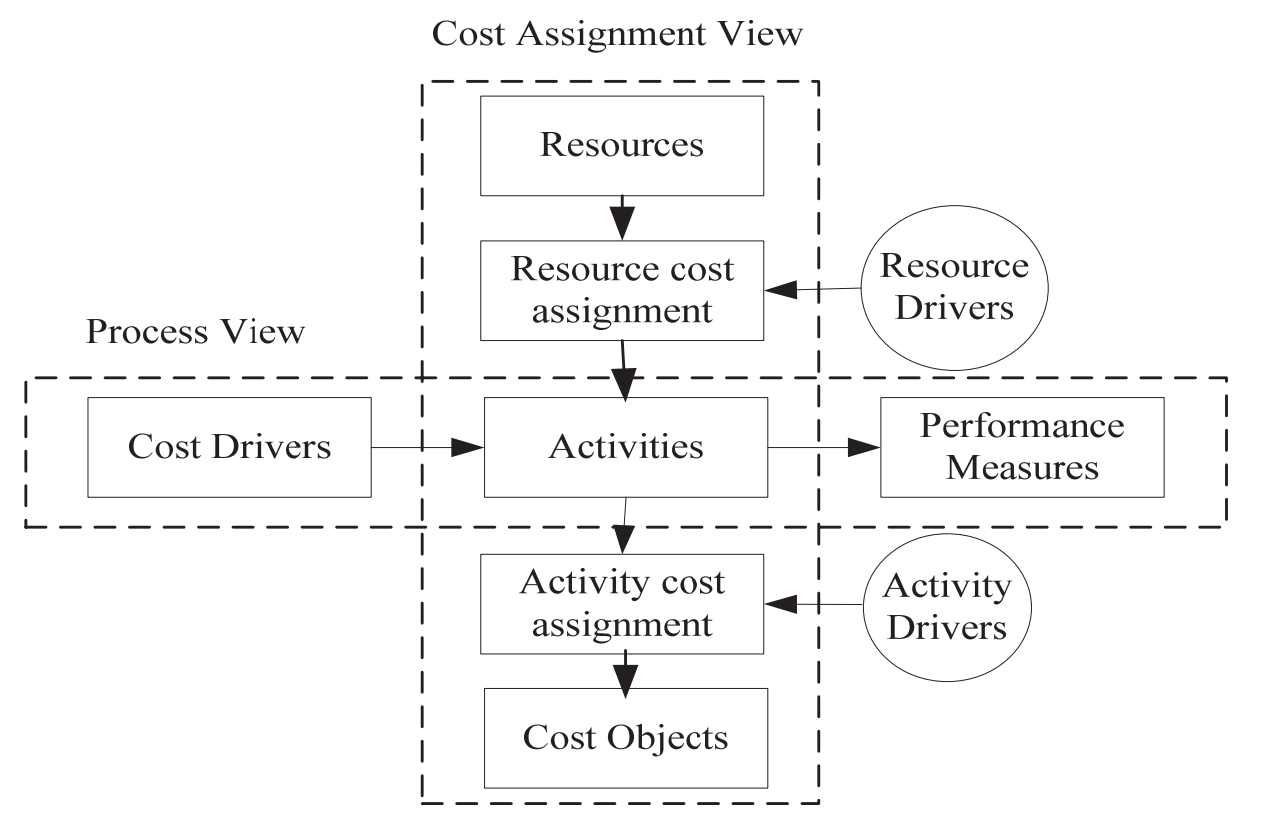

Furthermore, the process view in the ABM approach consists of cost drivers, activities and performance measures. The process view provides information about why those activities are categorised as a cost driver and how successful the activities are when measured with the achievement of the performance target.

'Cost drivers' refer to the factors that determine the workload of an activity and this workload can change the activity cost. For example, the quality of the raw material determines the raw material inspection methods. When the quality of the raw material is poor, then the company will conduct the $100 \%$ inspection method and this is expensive. Therefore, the $100 \%$ inspection method is a high-cost driver.

High-cost driver activity is a signal for companies to identify the roots of problems that arise and for them to take CA to eliminate or reduce the high-cost activity. When companies can get rid of such activities successfully, they can save money in the subsequent period. Moreover, the company can also acquire cost savings from the achievement of the performance targets. Table 2 explains the process view within the inbound logistics processes, which involves the cost drivers, value-added (VA) or NVA activities and performance measures. 
Table 1 Cost assignment view within the inbound logistics process at the shoe company

\begin{tabular}{|c|c|c|c|c|}
\hline Cost objects & Name of activities & $\begin{array}{l}\text { Activity } \\
\text { drivers }\end{array}$ & Resources & $\begin{array}{l}\text { Resource } \\
\text { drivers }\end{array}$ \\
\hline \multirow{10}{*}{$\begin{array}{l}\text { Activities related } \\
\text { to the } \\
\text { implementation } \\
\text { of the ISO } \\
9001: 2015 \\
\text { clause within } \\
\text { inbound } \\
\text { logistics }\end{array}$} & $\mathrm{A}=$ Control of document & $\begin{array}{l}\text { Man hour/ } \\
\text { batch }\end{array}$ & Employee & Man hour \\
\hline & $\begin{array}{l}\mathrm{B}=\text { Evaluation, selection, and } \\
\text { re-evaluation of suppliers }\end{array}$ & $\begin{array}{l}\text { Man hour/ } \\
\text { batch }\end{array}$ & Employee & Man hour \\
\hline & $\begin{array}{l}\mathrm{C}=\text { The purchasing process of raw } \\
\text { materials }\end{array}$ & $\begin{array}{c}\text { Man } \\
\text { hour/batch }\end{array}$ & Employee & Man hour \\
\hline & $\begin{array}{l}\mathrm{D}=\text { Calibration or internal } \\
\text { verification of measuring } \\
\text { instrument }\end{array}$ & $\begin{array}{l}\text { Machine } \\
\text { hour/unit }\end{array}$ & Machine & $\begin{array}{l}\text { Machine } \\
\text { hour }\end{array}$ \\
\hline & $\begin{array}{l}\mathrm{E}=\text { Receiving and in-coming } \\
\text { inspection of raw materials }\end{array}$ & $\begin{array}{c}\text { Man } \\
\text { hour/batch }\end{array}$ & Employee & Man hour \\
\hline & $\begin{array}{l}\mathrm{F}=\text { Sorting of bad/good raw } \\
\text { materials }\end{array}$ & $\begin{array}{l}\text { Man } \\
\text { hour/unit }\end{array}$ & Employee & Man hour \\
\hline & $\mathrm{G}=$ Process of material handling & $\begin{array}{c}\text { Man } \\
\text { hour/batch }\end{array}$ & Employee & Man hour \\
\hline & $\begin{array}{l}\mathrm{H}=\text { Maintenance of the warehouse } \\
\text { infrastructure }\end{array}$ & $\begin{array}{l}\text { Man hour/ } \\
\text { facility }\end{array}$ & Facility & Man hour \\
\hline & $\mathrm{I}=$ Inspection of raw material stock & $\begin{array}{l}\text { Man hour/ } \\
\text { unit }\end{array}$ & Employee & Man hour \\
\hline & $\mathrm{J}=$ Handling of damaged products & $\begin{array}{c}\text { Man } \\
\text { hour/unit }\end{array}$ & Employee & Man hour \\
\hline
\end{tabular}

Table 2 Process view within the inbound logistics process in the shoe companies

\begin{tabular}{lccc}
\hline Cost drivers & Name of activities & VA and NVA & Performance measures \\
\hline Activities in the & A & VA & Maximum percentage of defective \\
Purchasing process & B & VA & raw materials from suppliers is \\
& C & VA & $5 \%$ \\
D & VA & \\
E & NVA & \\
Activities in the & F & NVA & \\
Warehouse process & G & VA & Maximum percentage of raw \\
& H & VA & materials damaged in the \\
& I & NVA & \\
& J & NVA & \\
\hline
\end{tabular}

\subsection{Analysis}

In order to analyse the non-effective activity costs (high-cost activity or NVA activity), the company can use the Pareto diagram to analyse and take priority regarding the CAs (Juran and Godfrey, 1998). When the company succeeds in taking CAs effectively, based on the Pareto's principles, the company should succeed at reducing $80 \%$ of the noneffective activity costs. For example, as shown in Table 2, the incoming raw material 
inspection (activity of E) is a NVA activity. The activity driver uses man-hours to conduct the receiving and inspection activities. In this case, the company can use the method of $100 \%$ inspection, sample inspection or no-inspection. The inspection costs depend on the type of inspection method chosen. The company could reduce or eliminate the inspection cost significantly by selecting suppliers that provide good raw materials.

\subsection{CA and continuous improvement}

After taking CA effectively and when ensuring that the achievement of the performance targets is a success, in the next period, the company should re-plan their activities to reduce the high-cost activities and to increase the achievement of the performance targets. By implementing the PDCA cycle consistently, the company will acquire cost savings periodically.

\subsection{Reporting of the overhead costs and economic benefits}

Report writing consists of the overhead costs for the identification and analysis of the root causes of the problem and taking CAs related the high-cost activities and the achievement of the performance targets, cost savings for high-cost activities and the performance targets achieved, total overhead cost and total cost savings. Figure 3 describes the conceptual model and mathematical equations (1)-(4) used to measure the overhead cost, cost savings and payback period.

The company spent the overhead costs of $\mathrm{OC}(\mathrm{t})$ for the implementation of the ISO 9001 clause within the inbound logistics process in period $t(t=1.2, \ldots, t)$. For the efficient use of resources, the company identified high-cost activities using the Pareto diagram. Furthermore, the company analyses the root causes of the high-cost activities for its CAs. The company also evaluates and increases the performance targets periodically. For these activities, the company spends preventive overhead costs $(\mathrm{PC}(\mathrm{t}))$. The total overhead cost in period $t, \operatorname{TOC}(\mathrm{t})$, is $\mathrm{OC}(\mathrm{t})$ added to $\mathrm{PC}(\mathrm{t})$. If the CA is effective, then the company obtains cost savings of $\operatorname{CS}(\mathrm{t})$ by reducing the high-cost activities and the cost savings of PS(t) of the performance targets are achieved. Thus, the total cost savings in period $\mathrm{t}, \mathrm{TS}(\mathrm{t})$, are $\mathrm{CS}(\mathrm{t})$ added to $\mathrm{PS}(\mathrm{t})$.

In the next period, the company spends the overhead cost of $\mathrm{OC}(\mathrm{t}+1)$, where $\mathrm{OC}(\mathrm{t}+1)$ is the total overhead cost in the last period $\mathrm{t}$, TOC $(\mathrm{t})$ subtracted by the total cost savings in the last period $\mathrm{t}, \mathrm{TS}(\mathrm{t})$ or $[\mathrm{TOC}(\mathrm{t})-\mathrm{TS}(\mathrm{t})]$. From the development of the conceptual model, to measure the spent overhead costs, cost savings and payback periods, the following mathematical equations were used.

$$
\begin{aligned}
& \operatorname{TOC}(\mathrm{t})=\mathrm{OC}(\mathrm{t})+\mathrm{PC}(\mathrm{t}) \\
& \operatorname{TS}(\mathrm{t})=\mathrm{CS}(\mathrm{t})+\mathrm{PS}(\mathrm{t}) \\
& \mathrm{OC}(\mathrm{t}+1)=\mathrm{TOC}(\mathrm{t})-\mathrm{TS}(\mathrm{t})
\end{aligned}
$$

where is

OC( $(\mathrm{t})$ overhead costs for the activities of the ISO 9001 implementation within the inbound logistics process in period $t$ 
$\mathrm{PC}(\mathrm{t})$ overhead costs for analysis, the identification of root causes and the preventive and CAs for high-cost activities in period $t$

$\mathrm{CS}(\mathrm{t})$ cost savings resulting from reduction for high-cost activities in period $\mathrm{t}$

PS( $\mathrm{t}$ ) cost savings related to achieving the performance target in period $\mathrm{t}$

$\mathrm{TS}(\mathrm{t}) \quad$ total cost savings in period $\mathrm{t}$

TOC(t) total overhead costs in period $t$.

Figure 3 Conceptual model for measuring the overhead cost and economic benefits

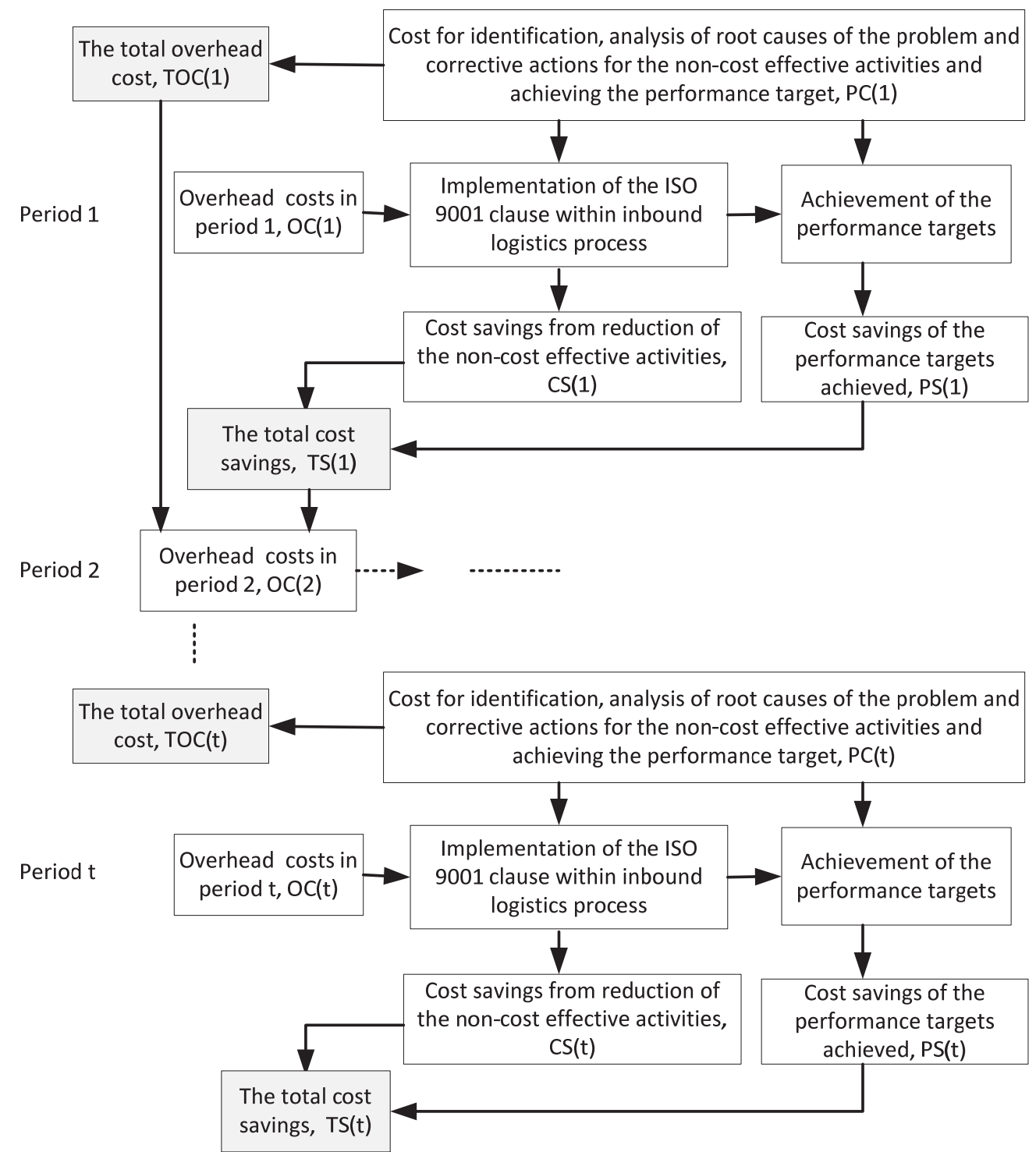

Furthermore, to calculate the payback periods for period $t, \operatorname{PP}(\mathrm{t})$, we used the mathematical equation as follows.

$$
\mathrm{PP}_{\mathrm{t}}=\frac{\sum_{\mathrm{t}=1}^{\mathrm{k}} \mathrm{TOC}_{\mathrm{t}}}{\sum_{\mathrm{t}=1}^{\mathrm{k}} \mathrm{TS}_{\mathrm{t}}}
$$


The payback period of the investment of the ISO 9001:2015 implementation program within inbound logistics can be obtained if the accumulated cost savings in period $t$, TS( $t)$, have exceeded the accumulated overhead costs in period $t$, TOC $(t)$ or $\sum_{\mathrm{t}=1}^{\mathrm{k}} \mathrm{TS}(\mathrm{t})>\sum_{\mathrm{t}=1}^{\mathrm{k}} \mathrm{TOC}(\mathrm{t})$.

\section{Result and discussion}

\subsection{Allocation and tracking of the overhead costs}

Table 3 explains the cost assignment view in stages 1 and 2 related to the overhead costs spent on the purchasing process (\#1) and the raw materials warehouse process (\#2) in period 1. There are two types of resource allocation, namely man and machine. The resource drivers for each of them are man-hours and machine hours respectively. The overhead cost to fulfil the ISO 9001:2015 clause within the inbound logistic process (\#1 and \#2) in period $1, \mathrm{OC}(1)$ is 8.060 million rupiah.

Table 3 The overhead cost to fulfill the ISO 9001:2015 clause within inbound logistics in period 1 (in thousand rupiah)

\begin{tabular}{lccccc}
\hline \multirow{2}{*}{$\begin{array}{l}\text { Name of } \\
\text { activities }\end{array}$} & Number of man hours in each process & \begin{tabular}{c} 
Frequency of \\
activity per \\
\cline { 2 - 3 } \cline { 5 - 6 } period
\end{tabular} & \multicolumn{2}{c}{ Cost of activities } \\
\hline A & $\# 1$ & 42 & 1 & Man & Machine \\
B & 30 & 0 & 2 & 1,400 & 0 \\
C & 3 & 0 & 12 & 2,880 & 0 \\
D & 12 & 0 & 1 & 0 & 300 \\
E & 0 & 0 & 12 & 480 & 0 \\
F & 2 & 0 & 12 & 480 & 0 \\
G & 2 & 4 & 12 & 960 & 0 \\
H & 0 & 10 & 2 & 400 & 0 \\
I & 0 & 16 & 2 & 640 & 0 \\
J & 0 & 10 & 2 & 400 & 0 \\
Total cost & 0 & & & 7,760 & 300 \\
\hline
\end{tabular}

Through the process view analysis in the ABM approach, the company identifies its noncost effective key activities. The Pareto diagram analysis (Figure 4) found that the five high-cost activities are: raw material purchasing (activity $\mathrm{C}$ ), documented information control (activity A), material handling (activity G), raw material stock inspection (activity I) and the receiving and in-coming inspection of raw material (activity E). Furthermore, the company took $\mathrm{CA}$ in order to reduce the high-cost activities as follows. For activity $\mathrm{C}$, they replaced the methods of the raw material direct inspection at the supplier's place by requesting the suppliers to send a certificate of analysis $(\mathrm{CoA})$ of the raw materials and conducting a sampling inspection. For activity A, they revised the procedures and work instructions for the supplier selection and evaluation. For activity G, they re-laid out 
the raw materials in the warehouse. For activity I, they conducted the raw material stock inspection periodically and activity E consisted of improving the acceptance sampling methods. The CA aimed to improve the achievement of the performance targets in the purchasing process and in the warehouse. The overhead cost of the CA, PC(1), is 2.100 million rupiah.

Figure 4 Cost per activity

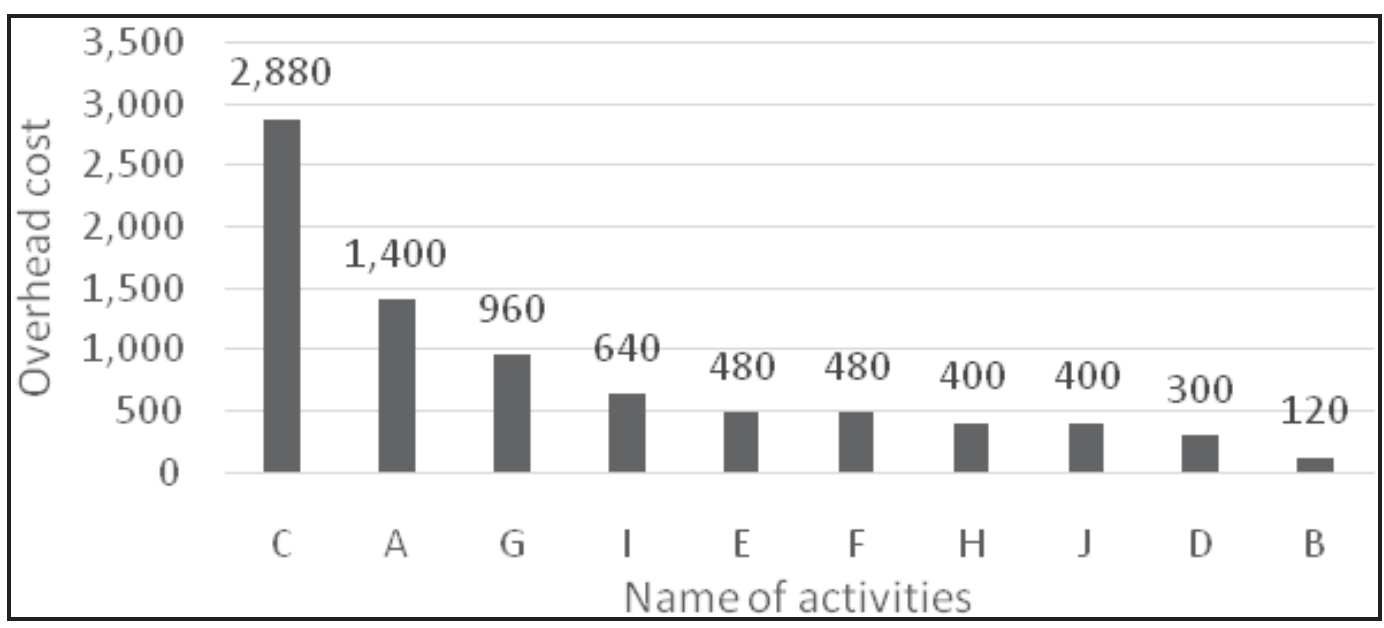

\subsection{Cost savings}

Table 4 showed an overhead cost before and after CA and the cost savings in period 1. The overhead cost of the high-cost activities was 6.360 million rupiah. During the implementation period, the company identified, analysed and took CAs for the high-cost activities. The results of the effectiveness of the CAs for the five high-cost activities are that the company acquired cost savings of 1.530 million rupiah.

Besides that, the company also acquired the cost savings from the performance targets achieved, with the detail calculation as follow.

a In terms of the purchasing process, the defected raw material target was reduced from $5 \%$ to $4.45 \%$. As the result, the company acquired cost savings of 1.050 million rupiah from $(5 \%-4.45 \%) \times 700$ sheets $\times 300,000$ rupiah.

b In terms of the raw materials warehouse process, the target of defected material in the warehouse reduced from $5 \%$ to $4.00 \%$. As the result, the company acquired cost savings of 2.100 million rupiah from $(5 \%-4 \%) \times 700$ sheets $\times 300,000$ rupiah.

The cost saving from the performance target achieved, PS(1) is 3.150 million rupiah. The total cost saving in period 1 is 4.680 million rupiah. When the total overhead cost in period 1 is subtracted by the total cost savings using the equation (3), the overhead cost, OC(2), at the beginning of period 2 is 5.480 million rupiah. In period 2, the company had the same mechanism (analysing via the Pareto diagram the roots cause of the problems and taking CA) to trace non-cost effective activities. For these activities, the company spent 1.450 million rupiah on preventive overhead costs, PC(2). The results of the CAs for the five high-cost activities are that the company obtained cost savings, CS(2), of 1.920 million rupiah. Table 5 showed overhead costs before and after the CA in period 2. 
Table 4 Cost saving of the effectiveness of CA for non-cost effective activities in period 1 (in thousand rupiah)

\begin{tabular}{lccc}
\hline Name of activities & Overhead cost before CA & Overhead cost after CA & Cost savings \\
\hline C & 2,880 & 2,200 & 680 \\
A & 1,400 & 1,100 & 300 \\
G & 960 & 700 & 260 \\
I & 640 & 450 & 190 \\
E & 480 & 380 & 100 \\
Total & 6,360 & 4,830 & 1,530 \\
\hline
\end{tabular}

Table 5 Cost saving of the effectiveness of the CA for non-cost effective activities in period 2 (in thousand rupiah)

\begin{tabular}{lccc}
\hline Name of activities & Overhead cost before CA & Overhead cost after CA & Cost savings \\
\hline C & 2,200 & 1,200 & 1,000 \\
A & 1,100 & 600 & 500 \\
G & 700 & 400 & 300 \\
I & 450 & 400 & 50 \\
E & 380 & 310 & 70 \\
Total & 4,830 & 4,455 & 1,920 \\
\hline
\end{tabular}

The cost savings from the performance targets achieved were as follows.

a In terms of the purchasing process, the defected raw material target was reduced from $4.45 \%$ to $3.9 \%$. As the result, the company acquired cost savings of 1.155 million rupiah.

b In terms of the raw material warehouse process, the target of the defected material in the warehouse was reduced from $4 \%$ to $3.2 \%$. As the result, the company acquired cost savings of 1.680 million rupiah.

Thus, the total cost saving in period 2 is 4.755 million rupiah. The total overhead cost in period 2 is 2.175 million rupiah. Using equations (1), (2), (3) and (4), Table 6 shows a summary of the overhead costs, cost savings and payback period in periods 1 and 2 .

Table 6 Overhead cost, cost savings and estimate of payback periods in periods 1 and 2 (in thousand rupiah)

\begin{tabular}{lll}
\hline Overhead cost & Cost savings & Estimate of payback periods \\
\hline Period 1 & & \\
$\mathrm{OC}(1)=8060$ & $\mathrm{CS}(1)=1,530$ & $\mathrm{PP}(1)=\frac{10,160}{4,680}=2.17$ periods \\
$\mathrm{PC}(1)=2,100$ & $\mathrm{PS}(1)=3,150$ & \\
$\mathrm{TOC}(1)=10,160$ & $\mathrm{TS}(1)=4,680$ & \\
Period 2 & & $\mathrm{PP}(2)=\frac{17,090}{9,435}=1.81$ periods \\
$\mathrm{OC}(2)=5,480$ & $\mathrm{CS}(1)=1,920$ & \\
$\mathrm{PC}(2)=1,450$ & $\mathrm{PS}(2)=2,835$ & \\
$\mathrm{TOC}(2)=6,930$ & $\mathrm{TS}(1)=4,755$ & \\
\hline
\end{tabular}


Table 7 Overhead cost, cost savings and payback periods for six periods (in thousand rupiah)

\begin{tabular}{cccccccc}
\hline$t$ & $O C(t)$ & $P C(t)$ & $C S(t)$ & $P S(t)$ & $T O C(t)$ & $T S(t)$ & $P P(t)$ \\
\hline 1 & 8,060 & 2,100 & 1,530 & 3,150 & 1,0160 & 4,680 & 2.17 \\
2 & 5,480 & 1,450 & 1,920 & 2,835 & 6,930 & 4,755 & 1.81 \\
3 & 2,175 & 1,050 & 2,400 & 2,310 & 3,225 & 4,710 & 1.44 \\
4 & $-(1,485)^{*}$ & 800 & 1,100 & 2,100 & $-(685)^{*}$ & 3,200 & 1.13 \\
5 & $-(3,885)^{*}$ & 600 & 500 & 1,260 & $-(3,285)^{*}$ & 1,760 & 0.86 \\
6 & $-(5,045)^{*}$ & 500 & 300 & 1,050 & $-(4,545)^{*}$ & 1,350 & 0.58 \\
\hline
\end{tabular}

Note: *overhead cost less than cost savings.

Table 7 summarises the total overhead cost $(\mathrm{TOC}(\mathrm{t}))$ and cost saving $(\mathrm{S}(\mathrm{t}))$, as well as estimate of the payback periods $(\mathrm{PP}(\mathrm{t}))$ for the implementation of ISO 9001 within the inbound logistics for 6 periods (in thousand rupiah).

As shown in Table 7, the company acquired cost savings from implementing the ISO 9001:2015 clause within the inbound logistics process for each period. At the end of period 3, the company acquired cost savings of 4.710 million rupiah. If this saving is subtracted by the total overhead cost at the end of period 3, then at the beginning of period 4, the company has savings of 1.485 million rupiah and this continues to increase in periods 5 and 6 . Although the company acquired savings at the beginning of period 4, this does not mean that the payback period occurs in period 4 . This is because by using equation (4), the company acquired a payback period of the investment in period 5 (Figure 5).

Figure 5 Accumulated overhead costs versus accumulated cost savings for two performance indicators

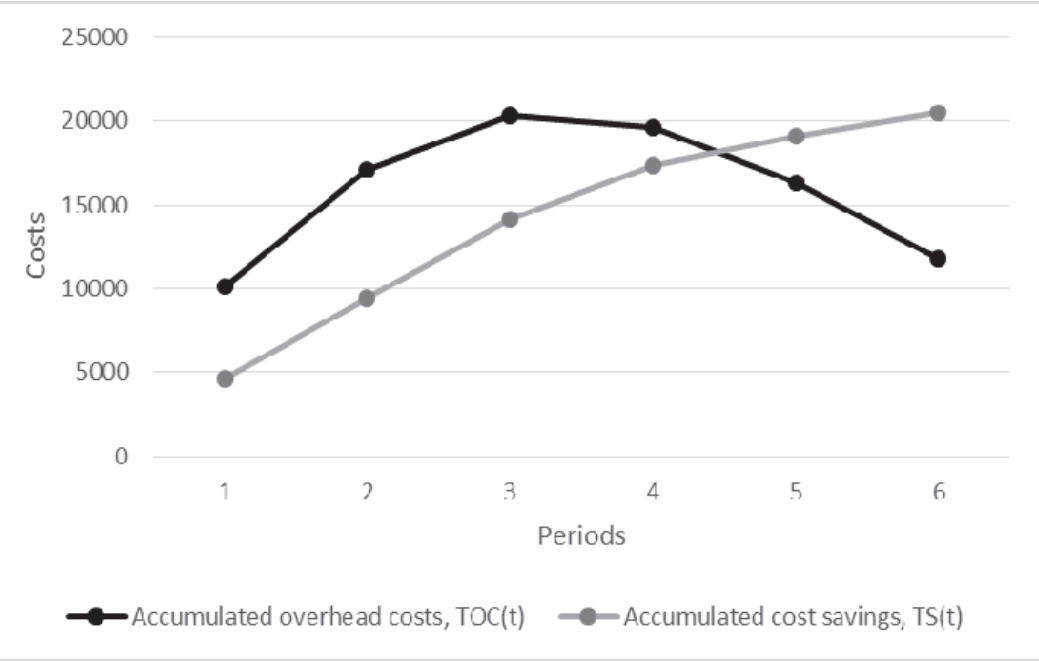

In addition, it should be noted that in Table 7, the contribution of the cost savings from the achievement of the two performance targets within the inbound logistics process was significantly large at the beginning of the period. It slowed down in subsequent periods. The difficulty related to achieving the performance target is because at the beginning of the period, the company has set a high performance target, namely the maximum percentage of defects in the raw materials from the suppliers and the in warehouses as $5 \%$. Once a company succeeds in achieving a high performance target at the beginning of 
the period (for example, a performance target that is reached of $4 \%$ ), then the company finds it difficult to achieve the performance targets that increase from period to period.

\subsection{Discussion}

The ABM approach allows companies to measure how much the overhead costs and cost savings are for the implementation of ISO 9001:2015 in the purchasing process and raw material warehouse process. The overhead costs for the purchasing process are related to the quality level of the raw materials from the suppliers, such as the cost of activities: selection, evaluation and re-evaluation of supplier performance; raw material purchasing; receiving and inspection of the purchased raw material; calibration of instruments for the raw material inspection and the sorting of the good/bad raw materials. If these activities are effective, then both the companies and suppliers can eliminate high-cost activities such as not needing to inspect the supplier's place directly (Sawan et al., 2018) or reducing the return of the raw materials (Zubar et al., 2019). As a result, there was a significant improvement in the quality of the raw material of the shoes. Wood (2013) stated that for this condition, the company needs to acquire a return on investment from the reduction in the cost of raw material defects and improve the quality of the raw materials.

By using the company's operational data, this case study research not only confirmed what was stated by Sampaio et al. (2012) that the application of ISO 9001:2015 has an impact on improving the quality of the processes. The company should also be able to improve the efficiency of the usage of the financial resources through success in order to reduce the high-cost activities and the achievement of the performance target.

The results of the study allow the company to trace the overhead costs to improve and reduce their high-cost activities periodically. Moreover, the company will be able to learn the pattern of the accumulated overhead costs and cost savings for each period in order to estimate the return period of the investment. Therefore, the study results also answer Øvretveit's (2000) questions about how much it costs to improve the quality and how much the cost savings obtained for each period are. Another question asks how long the investment return period is.

This study shows that at certain performance target limits where companies have difficulty achieving the targets (see Table 7, where the cost savings, PS(t), are slowing down continually after period 4), the companies should add new performance indicators to keep continually acquiring cost savings.

The setting up of a number of performance indicators in a business process should be a concern of the company. This is because the number of performance indicators affects the cost savings acquired. For example, in this case, the company only has one performance indicator in the inbound logistics process, namely the defective raw material from the supplier with the target maximum defect rate being $5 \%$. Thus, the overhead cost and cost savings are as follows (Table 8).

Table 8 and Figure 6 shows that the cost savings from achieving one performance indicator dropped dramatically compared to two performance indicators (see Table 7 and Figure 5). As a result, for the six periods of measurement of the overhead costs and cost savings, companies did not reach the period of return on investment. 
Table 8 Overhead cost, cost savings and payback periods for one performance indicator

\begin{tabular}{cccccccc}
\hline$t$ & $O C(t)$ & $P C(t)$ & $C S(t)$ & $P S(t)$ & $T O C(t)$ & $T S(t)$ & $P P(t)$ \\
\hline 1 & 8,060 & 2,100 & 1,530 & 1,050 & 10,160 & 2,580 & 6.43 \\
2 & 7,580 & 1,450 & 1,920 & 1,155 & 9,030 & 3,075 & 4.12 \\
3 & 5,955 & 1,050 & 2,400 & 1,890 & 7,005 & 4,290 & 2.93 \\
4 & 2,715 & 800 & 1,100 & 1,050 & 3,515 & 2,150 & 2.68 \\
5 & 1,365 & 600 & 500 & 630 & 1,965 & 1,130 & 2.59 \\
6 & 835 & 500 & 300 & 420 & 1,335 & 720 & 2.55 \\
\hline
\end{tabular}

Figure 6 Accumulated overhead costs versus accumulated cost savings for one performance indicator

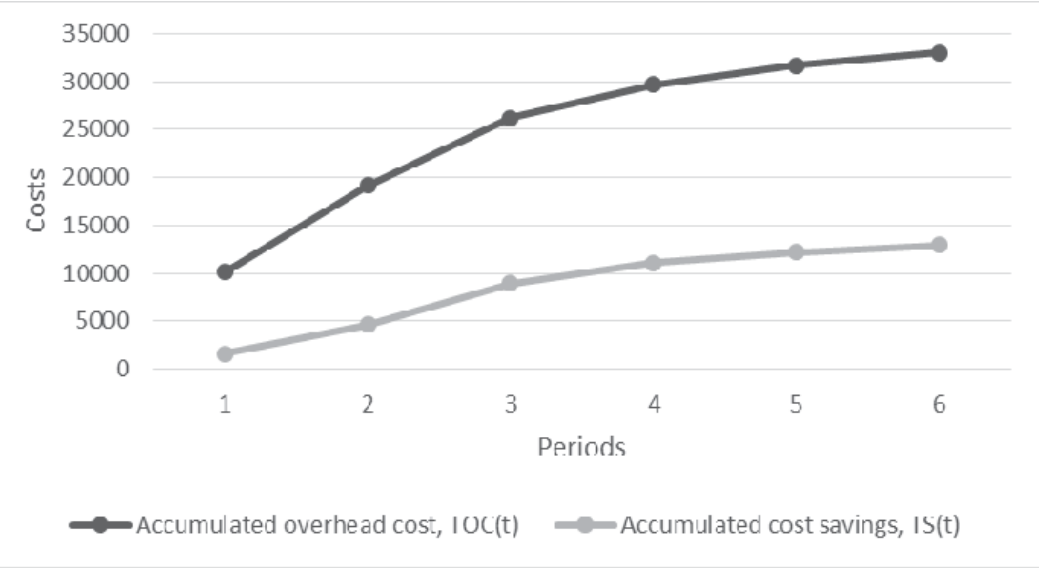

\section{Conclusions}

This study complements the previous empirical survey research in which a number of researchers agreed that implementing ISO 9001 in organisations had an impact on the operational performance. In the developed model, the effect of the operational performance was measured and converted into units of money as a cost savings unit. Thus, the company was able to measure not only the overhead costs but also the economic effect of implementing the ISO 9001 clause periodically.

\subsection{Theoretical contributions}

This model includes the variable of overhead costs for carrying out activities and achieving the operational performance of a business process. Research that addresses the integration between overhead costs and the economic impact of quality improvement programs is still rare.

Although this study used a study case for the numerical examples in the business process of a manufacturing company, the conceptual model and mathematical equations developed are generic and can be applied in all business processes of other manufacturing companies. Through the ABM approach, conceptual model and mathematical equations, other companies can use it to measure the program investment to improve the quality and 
economic impact in other business processes, as well as to measure the return period of the investment.

\subsection{Managerial implications}

In addition to a number of researchers who have agreed that there is a positive impact for the company from implementing ISO 9001, there are a number of researchers who revealed that the top management felt that they did not contribute quantitatively to the implementation of ISO 9001 (Sampaio et al., 2011; Ilkay and Aslan, 2012). They only feel that there is an improvement in the internal organisation but they are confused about how to measure it based on the operational data of the organisation. By using this model, top management will be able to measure how much the overhead costs are, how much money can be saved and when the investment will return and be profitable.

Top management, who has information about the costs incurred for investing in a quality program, the economic benefits acquired and the return period of investment in quality improvement programs, are not hesitant to support the implementation of quality improvement programs such as the application of ISO 9001.

\subsection{Limitations of the research and future research directions}

This research has a number of limitations, such as only discussing one business process in the company. Future researchers can expand on this by discussing more than one business process. In addition, from the results of the developing conceptual models and mathematical equations, future researchers can also develop more general models by studying the distribution patterns of the overhead costs and economic benefits for a number of performance indicators and targets.

\section{References}

Aba, E.K., Badar, M.A. and Hayden, M.A. (2016) 'Impact of ISO 9001 certification on firms financial operating performance', International Journal of Quality \& Reliability Management, Vol. 33, No. 1, pp.78-89.

Abuhav, I. (2017) ISO 9001:2015: A Complete Guide to Quality Management Systems, CRC Press-Taylor \& Francis Group, Boca Raton, FL.

Alglawe, A. et al. (2019) 'Supply chain network design based on cost of quality and quality level analysis', The TQM Journal, Vol. 31, No. 3, pp.467-490, DOI: 10.1108/TQM-11-2018-0151.

Alizadeh, A., Chehrehpak, M. and Ashlaghi, M.J. (2016) 'A decision support system for vendor selection and quota allocations using dependent and independent criteria', International Journal Services and Operations Management, Vol. 23, No. 2, pp.201-216.

Antunes, M.G., Quirós, J.T. and Justino, M.R. (2018) 'Total quality management and quality certification: effects in organisational performance', International Journal Services and Operations Management, Vol. 29, No. 4, pp.439-461.

Barouch, G. and Bey, C. (2018) 'Cost of quality and process model: improving accounting tools for attaining higher environmental efficiency', Journal of Cleaner Production, Vol. 181, pp.192-200, Elsevier Ltd.

British Standard (1992) Guide to the Economics of Quality - Part 1 Process Cost Model, BSI. 
Chatzipetrou, E. and Moschidis, O. (2018) 'A multidimensional longitudinal meta-analysis of quality costing research', International Journal of Quality \& Reliability Management, Vol. 35, No. 2, pp.405-429, DOI: 10.1108/IJQRM-08-2016-0117.

Chopra, A. and Garg, D. (2011) 'Behavior patterns of quality cost categories', TQM Journal, Vol. 23, No. 5, pp.510-515.

Crombie, G. (1993) 'Measure for measure', The TQM Magazine, Vol. 5, No. 4, pp.47-49.

Emblemsvag, J. and Bras, B. (2001) Activity-based Cost and Environmental Management. A Different Approach to ISO 14000 Compliance, Springer Science+Business Media, New York, DOI: $10.1007 / 978-1-4419-8604-7$.

Farooq, M.A. et al. (2017) 'Cost of quality: evaluating cost-quality trade-offs for inspection strategies of manufacturing processes', International Journal of Production Economics, November, Vol. 188, pp.156-166, Elsevier BV.

Fons, L.A.S. (2011) 'Measuring economic effects of quality management systems', The TQM Journal, Vol. 23, No. 4, pp.458-474.

Fons, L.S. (2013) 'Healthcare quality costs based on an ISO 9000 model', Leadership in Health Services, Vol. 26, No. 3, pp.184-195.

Goulden, C. and Rawlins, L. (1997) 'Quality costing: the application of the process model within a manufacturing environment', International Journal of Operations \& Production Management, Vol. 17, No. 2, pp.199-210.

Greasley, A. and Smith, C.M. (2017) 'Using activity-based costing and simulation to reduce cost at a police communications centre', Policing: An International Journal of Police Strategies \& Management, Vol. 40, No. 2, pp.426-441, DOI: 10.1108/PIJPSM-03-2016-0044.

Gupta, V., Garg, D. and Kumar, R. (2018) 'Performance evaluation of TQM attainment in Indian manufacturing sector performance evaluation of TQM attainment in Indian manufacturing sector', Int. J. Services and Operations Management, Vol. 29, No. 2, pp.184-213, DOI: 10.1504/IJSOM.2018.089252.

Halis, M. and Oztas, A. (2002) 'Quality cost analysis in IS0-9000-certified Turkish companies', Managerial Auditing Journal, Vol. 17, Nos. 1/2, pp.101-104.

Hofmann, E. and Bosshard, J. (2017) 'Supply chain management and activity-based costing Current status and directions for the future', International Journal of Physical Distribution \& Logistics Management, Vol. 47, No. 8, pp.712-735, DOI: 10.1108/IJPDLM-04-2017-0158.

Ilkay, M.S. and Aslan, E. (2012) 'The effect of the ISO 9001 quality management system on the performance of SMEs', International Journal of Quality \& Reliability Management, Vol. 29, No. 7, pp.753-778.

International Organization for Standardization (ISO) (2013) Economic Benefits of Standards - ISO Methodology 2.0, ISO Central Secretariat, Geneva.

Juran, J.M. and Godfrey, A.B. (1998) Juran's Quality Control Handbook, McGraw-Hill, New York, NY.

Kaplan, R.S. and Anderson, S.R. (2007) Time-Driven Activity-Based Costing: A Simpler and More Powerful Path to Higher Profits, Harvard Business School Press Books, Boston, Massachusetts.

Kerfai, N., Ghadhab, B.B. and Malouche, D. (2016) 'Performance measurement and quality costing in Tunisian manufacturing companies', The TQM Journal, Vol. 28, No. 4, pp.588-596, DOI: 10.1108/TQM-10-2013-0119.

Khalili, A., Ismail, M.Y. and Karim, A.N.M. (2018) 'Quality management system and sustainability: a Malaysian perspective', International Journal Services and Operations Management, Vol. 30, No. 3, pp.286-317.

Khataie, A.H. and Bulgak, A.A. (2013) 'A cost of quality decision support model for lean manufacturing: activity-based costing application', International Journal of Quality \& Reliability Management, Vol. 30, No. 7, pp.751-764. 
Letza, S.R. and Gadd, K. (1994) 'Should activity-based costing be considered as the costing method of choice for total quality organizations?', The TQM Magazine, Vol. 6, No. 5, pp.57-63.

Malik, T.M. et al. (2016) 'Cost of quality: findings of wood products' manufacturer', The TQM Journal, Vol. 28, No. 1, pp.2-20.

Mazzaw, R. and Alawamleh, M. (2019) 'Managing quality within existing supply chains: case studies from Jordan managing quality within existing supply chains: case studies from Jordan', Int. J. Services and Operations Management, Vol. 32, No. 1, pp.44-66, DOI: 10.1504/IJSOM.2019.10018080.

Modgil, S. and Sharma, S. (2017) 'Linkage between total quality and supply chain management practices and operational performance: a review', Int. J. Services and Operations Management, Vol. 27, No. 1, pp.210-238, DOI: 10.1504/IJSOM.2017.10003963.

Omar, M.K. and Murgan, S. (2014) 'An improved model for the cost of quality', International Journal of Quality \& Reliability Management, Vol. 31, No. 4, pp.395-418.

Øvretveit, J. (2000) 'The economics of quality - a practical approach', International Journal of Health Care Quality Assurance, Vol. 13, No. 5, pp.200-207.

Plewa, M., Kaiser, G. and Hartmann, E. (2016) 'Is quality still free?: Empirical evidence on quality cost in modern manufacturing', International Journal of Quality and Reliability Management, Vol. 33, No. 9, pp.1270-1285.

Psomas, E. and Pantouvakis, A. (2015) 'ISO 9001 overall performance dimensions: an exploratory study', The TQM Journal, Vol. 27, No. 5, pp.519-531.

Regina, M. et al. (2018) 'Operational capabilities in an emerging country: quality and the cost trade-off effect', International Journal of Quality \& Reliability Management, Vol. 35, No. 8, pp.1617-1638, DOI: 10.1108/IJQRM-04-2017-0061.

Rosiawan, M., Singgih, M.L. and Widodo, E. (2018) 'The benefit attributes of the National Standard (SNI) Product Indonesian', The International Cooperation for Education about Standardization (ICES) 2018 Conference Joint International Conference with 5th Annual Conference on Industrial and System Engineering (ACISE), Yogyakarta, Indonesia, 3-5 July, pp.3-5.

Sampaio, P., Saraiva, P. and Monteiro, A. (2012) 'ISO 9001 certification pay-off: myth versus reality', International Journal of Quality \& Reliability Management, Vol. 29, No. 8, pp.891-914.

Sampaio, P., Saraiva, P. and Rodrigues, A.G. (2011) 'The economic impact of quality management systems in Portuguese certified companies', International Journal of Quality \& Reliability Management, Vol. 28, No. 9, pp.929-950.

Sawan, R., Low, J.F. and Schiffauerova, A. (2018) 'Quality cost of material procurement in construction projects', Engineering, Construction and Architectural Management, Vol. 25, No. 8, pp.974-988, DOI: 10.1108/ECAM-04-2017-0068.

Schiffauerova, A. and Thomson, V. (2006) 'A review of research on cost of quality models and best practices', International Journal of Quality \& Reliability Management, Vol. 23, No. 6, pp.647-669.

Singh, J. and Singh, H. (2018) 'Modelling of barriers and initiatives of continuous improvement approach for enhancing the performance of SMEs of Northern India', International Journal Services and Operations Management, Vol. 29, No. 2, pp.184-213.

Starke, F. et al. (2012) 'Impact of ISO 9000 certification on firm performance: evidence from Brazil', Management Research Review, Vol. 35, No. 10, pp.974-997.

Sturm, S., Kaiser, G. and Hartmann, E. (2019) 'Long-run dynamics between cost of quality and quality performance dynamics', International Journal of Quality \& Reliability Management, DOI: 10.1108/IJQRM-05-2018-0118.

Tsai, W-H. (1998) 'Quality cost measurement under activity-based costing', International Journal of Quality \& Reliability Management, Vol. 15, No. 7, pp.719-752. 
Tzelepis, D. et al. (2006) 'The effects of ISO 9001 on firms' productive efficiency', International Journal of Operations \& Production Management, Vol. 26, No. 10, pp.1146-1165.

Wood, D.C. (2013) Principles of Quality Costs, ASQ Quality Press, Milwaukee, WI.

Zubar, H.A., Ravikumar, M.M. and Parthiban, P. (2019) 'An integrated approach for performance evaluation of suppliers in manufacturing industries', International Journal of Service and Operations Management, Vol. 32, No. 3, pp.307-326. 


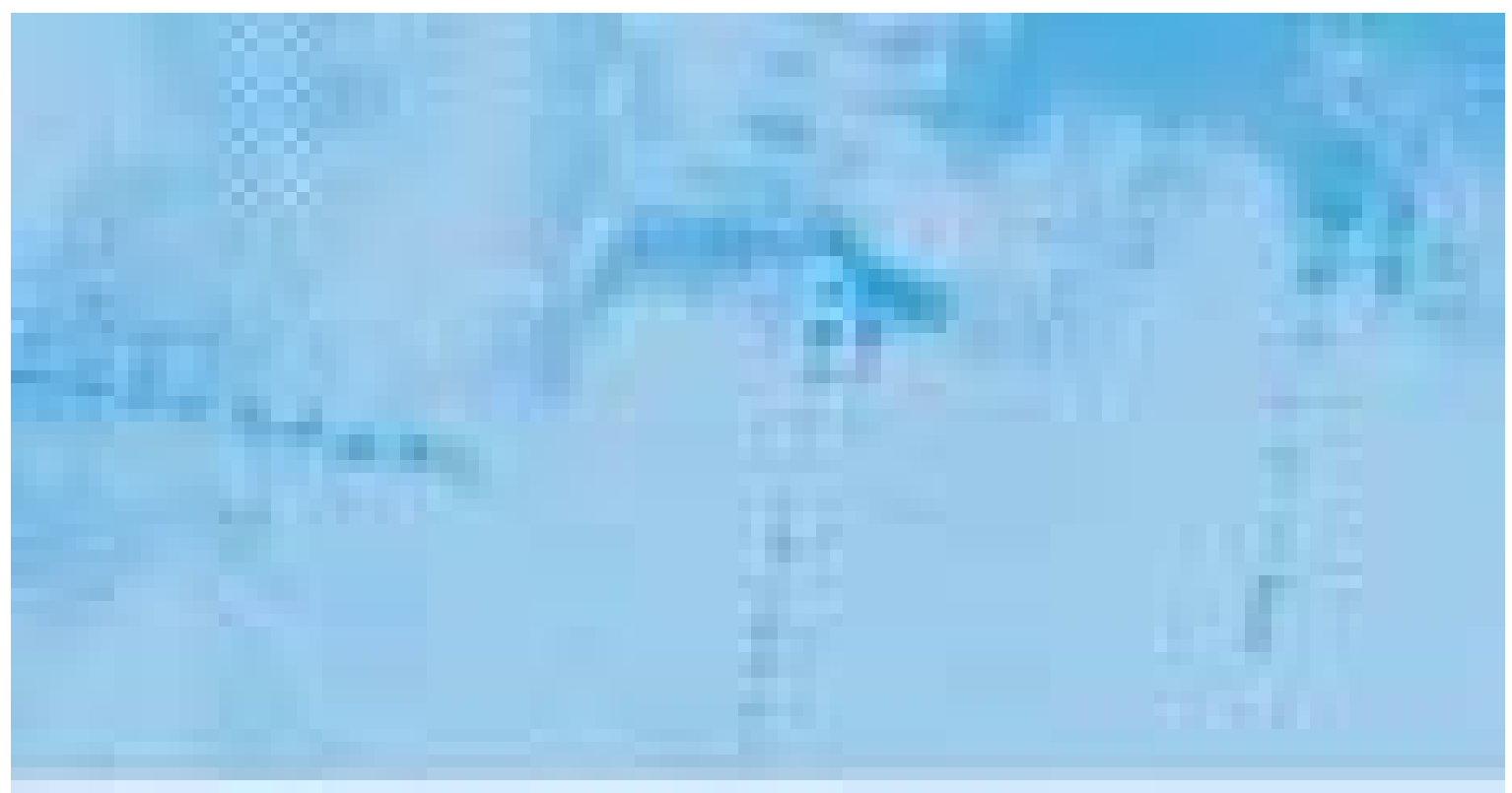

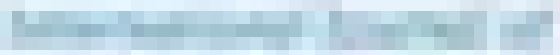

\section{Services and Operations: Management}

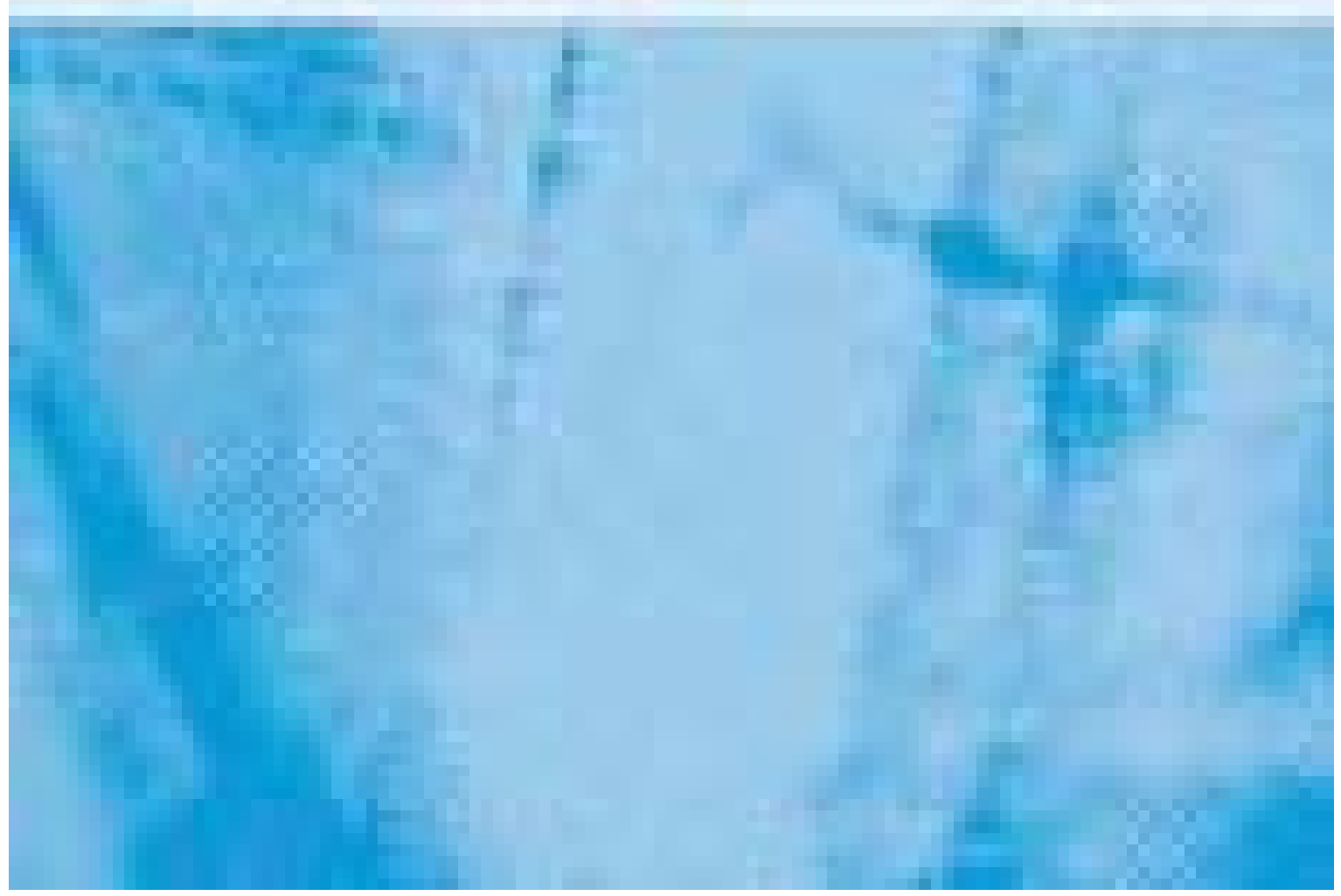




\section{International Journal of Services and Operations Management}

(.) This journal also publishes Open Access articles

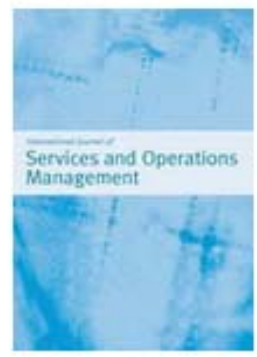

Editor in Chief

Prof. Angappa Gunasekaran

ISSN online

1744-2389

ISSN print

$1744-2370$

12 issues per year

Subscription price

CiteScore 2020

1.2

\section{Scopus}

Globalisation of market and operations places tremendous pressure on productive management of services and manufacturing enterprises. Services are increasingly important in today's developed economies. Nevertheless, manufacturing plays a major role in national economies and is essential for the survival of service organisations. Considering the globalisation of services and manufacturing, a journal focusing on global perspective of operations management is of paramount importance. IJSOM focuses on new strategies, techniques and technologies for improving productivity and quality in both manufacturing and services. 


\section{Editor in Chief}

- Gunasekaran, Angappa, Penn State Harrisburg, USA (an.gunasekaran@gmail.com)

\section{Associate Editor}

- Subramanian, Nachiappan, University of Sussex, UK

\section{Editorial Board Members}

- Antony, Jju, Heriot-Watt University, UK

- Apte, Uday, Southern Methodist University, USA

- Babbar, Sunil, Florida Atlantic University, USA

- Beresford, Anthony, Cardiff University, UK

- Berry, Wiliam, Queens University of Charlotte, USA

- Bommer, Michael, Clarkson University, USA

- Bond, Chris, UK

- Buddress, Lee, Portland State University, USA

- Bueno Campos, Eduardo, Universidad Autónoma de Madrid, Spain

- Burns, Neil, Loughborough University, UK

- Chen, Chialin, Queen's University, Canada

- Clegg. Ben, Aston University, UK

- Damien, Paul, The University of Texas at Austin, USA

- Das, Ajay, Baruch College, USA

- Davis, Mark, Bentley College, USA

- Dobson, Gregory, University of Rochester USA

- Evans, James R., University of Cincinnati, USA

- Eynan, Amit, University of Richmond, USA

- Franceschini, Fiorenzo, Politecnico di Torino, Italy

- Fransoo, Jan, Technische Universiteit Eindhoven, Netherlands

- Gindy, Nabill University of Nottingham, UK

- Goodwin, Paul, University of Bath, UK

- Hertz, Susanne, Jonkoping International Business School, Sweden

- Hua, Zhongsheng, University of Science and Technology of China, China

- Huchzermeier, Arnd, WHU - Otto-Beisheim Graduate School of Management, Germany

- Kohler, Pierre, Swiss Business School, Switzerland

- Koulamas, Christos, Florida International University, USA

- Li, Shanling, McGill University, Canada

- Lyu, JrJung, National Cheng Kung University, Taiwan

- Macbeth, Douglas K., University of Southampton, UK

- MacBryde, Jillian, University of Strathclyde, UK

- Mathieu, Richard G. Queens University of Charlotte, USA

- McCarthy, lan, Simon Fraser University, Canada

- McComb, Sara, Purdue University, USA

- McDermott, Chris, Rensselaer Polytechnic Institute, USA

- Mercieca, Charles, UN-NGO, USA

- Newman, W. Rocky, Miami University, USA

- Olson, David L. University of Nebraska - Lincoln, USA

- Oztekin, Asil, University of Massachusetts Lowell, USA

- Parlar, Mahmut, McMaster University, Canada

- Pentico, David W, Duquesne University, USA

- Pesnel, Eric, ESCP-EAP, France

- Robb, David, Tsinghua University, China

- Rosenthal, Stephen R, Boston University, USA

- Russell, Robert A., University of Tulsa, USA

- Sethuraman, Kannan, University of Melbourne, Australia

- Smith, Marilyn, Winthrop University, USA

- Sum, Chee Chuong, National University of Singapore, Singapore

- Swamidass, Paul M., Auburn University, USA

- Tirtiroglu, Ercan, University of Adelaide, Australia

- Twigg, David, University of Sussex, UK

- Viswanathan, S, Nanyang Technological University, Singapore

- Vonderembse, Mark University of Toledo, USA

- Zemel, Eitan, New York University, USA 


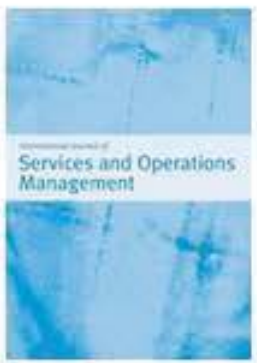

\title{
International Journal of Services and Operations Management
}

\section{Vol.40 No.1}

\author{
Pages Title and author(s) \\ 1-22 Activity-based management as economic effect measurement for implementing ISO \\ 9001:2015 clause \\ Muhammad Rosiawan; Moses Laksono Singgih; Erwin Widodo \\ DOI: $10.1504 /$ IJSOM.2021.117649 \\ 23-46 Measuring effectiveness of ticketing services of public transportation \\ Govind Nath Srivastava; Harsh Purohit \\ DOI: $10.1504 /$ USOM.2021.117645
}

An optimisation approach for simulation operator allocation and job dispatching rule in a cellular manufacturing system

Saeid Jafarzadeh Ghoushchi; Ali Abbasi

DOI: 10.1504/IJSOM.2021.117644

State of art review on strategies, tools and indicators of sustainable manufacturing

R.M. Thirupathi; S. Vinodh; S. Dhanasekaran

DOI: $10.1504 /$ ISOM.2021.117643

87108 Comparison of discrete and continuous travel time models for a multi-aisle AS/RS under different operating conditions

Vishwesh Singbal; Gajendra Kumar Adil

DOI: $10.1504 /$ USOM.2021.117658

109-141 Analysing the sustainability of plastic part manufacturing supply chain using matrixdigraph-based approach K. Sivakumar; R. Jeyapaul; K.E.K. Vimal; V. Raja Sreedharan

DOI: $10.1504 /$ ISOM.2021.117683 